\title{
PROBLEM MANAJEMEN PESANTREN, SEKOLAH, MADRASAH: PROBLEM MUTU DAN KUALITAS INPUT-PROSES-OUTPUT
}

\section{Fata Asyrofi Yahya}

Institut Agama Islam Roudlotul Mujahidin (IAIRM) Ngabar Ponorogo Email: fataasyrofi26@gmail.com

DOI: http://dx.doi.org/10.20885/tarbawi.vol8.iss1.art6

\begin{abstract}
Islamic boarding schools (pesantren), schools and madrasab are providers of education in Indonesia that are regulated and recognized by the government. Historically the emergence of the three institutions had been closely related and each has distinctive characteristics. As an educational system, the three institutions have input, process and output components. These three components must be managed and regulated by a professional management to produce a quality implementation of education. In their development, the three institutions are always faced with various problems in terms of input, process or output. Identification of the problems that exist is the first step in the effort towards continuous improvement of the quality of the educational institutions.
\end{abstract}

Keywords: problems of pesantren management, schools, madrasah

\begin{abstract}
Abstrak
Pesantren, sekolah dan madrasah merupakan lembaga penyelenggara pendidikan di Indonesia yang diatur dan diakui oleh pemerintah. Secara historis kemunculan ketiga lembaga tersebut mempunyai hubungan antara satu dengan lainnya sehingga mempunyai ciri khas masing-masing. Sebagai sebuah sistem pendidikan ketiga lembaga tersebut mempunyai komponen input, proses dan output. Ketiga komponen tersebut harus dikelola dan diatur dengan manajemen yang professional untuk menghasilkan penyelenggaraan pendidikan yang bermutu dan berkualitas. Dalam perjalanannya ketiga lembaga tersebut selalu dihadapkan dengan berbagai problem dalam pengembangannya, baik problem di dalam input, proses ataupun outputnya. Identifikasi terhadap problematika yang ada
\end{abstract}


merupakan langkah awal dalam upaya perbaikan secara terus-menerus terhadap mutu dan kualitas lembaga-lembaga pendidikan tersebut.

Kata Kunci: Problematika Manajemen Pesantren, Sekolah dan Madrasah.

\section{Pendahuluan}

Pendidikan merupakan salah satu upaya untuk membangun dan meningkatkan mutu SDM menuju era globalisasi yang penuh dengan tantangan sehingga disadari bahwa pendidikan merupakan sesuatu yang sangat fundamental bagi setiap individu. Oleh karena itu, kegiatan pendidikan tidak dapat diabaikan begitu saja, terutama dalam memasuki era persaingan yang semakin ketat, tajam, berat pada abad millenium ini (Rivai, 2009: 1).

Duniapendidikan diIndonesia masih diliputiberbagaipermasalahan, setidaknya masih berkutat pada beberapa hal, yaitu: pertama; belum optimalnya kegiatan pembelajaran karena terkendala keterbatasan sarana dan prasarana terutama di lembaga pendidikan yang terletak di kota kecil dan pelosok. Kedua; keberadaan data nasional yang diperoleh dari hasil ujian nasional, tidak sepenuhnya didapat melalui proses ujian nasional yang penuh kejujuran. Ketiga; sudah menjadi rahasia umum bahwa masih banyak birokrat di bidang pendidikan yang melakukan korupsi, kolusi dan nepotisme (KKN) (Baharuddin, 2010: 3). Berbagai permasalahan di atas dapat diidentifikasi terletak pada input, proses ataupun output pada lembaga pendidikan. Hal ini harus segera ditangani dan dicarikan solusi pemecahannya untuk menciptakan pendidikan nasional yang lebih berkualitas.

Pesantren, sekolah dan madrasah merupakan lembaga penyelenggara pendidikan di Indonesia. Masing-masing lembaga pendidikan tersebut telah diatur dan diakui oleh pemerintah dalam undang-undang nomer 20 tahun 2003 tentang Sistem Pendidikan Nasional. Pesantren ditetapkan sebagai salah satu bentuk lembaga pendidikan kegamaan (Pasal 30 ayat 4). Sedangkan sekolah dan madrasah merupakan lembaga pendidikan formal yang mempunyai jenjang pendidikan dasar dan menengah (Pasal 17 dan 18).

Secara historis munculnya sistem pendidikan pesantren, sekolah dan madrasah di Indonesia mempunyai keterkaitan antara satu dengan yang lainnya. Sistem pendidikan yang pertama kali muncul di Indonesia adalah 
pesantren, sebab lembaga yang serupa dengan pesantren ini sebenarnya sudah ada sejak pada masa kekuasaan Hindu-Budha. Sehingga Islam tinggal meneruskan dan mengislamkan lembaga pendidikan yang sudah ada (Madjid, 1997:3). Lembaga ini di Jawa disebut pesantren, di Aceh dengan rangkang dan dayah, di Sumatra Barat dengan surau (Daulay, 2001: ix).

Kemudian pada abad ke-17 lembaga pendidikan sekolah dibangun oleh VOC di Ambon, selanjutnya mengalami perkembangan secara bertahap diseluruh Indonesia. Pada zaman kolonial Belanda dapat dicermati betapa Belanda telah mempraktekkan kebijakan pendidikan yang diskriminatif, sehingga akibatnya masyarakat pribumi sangat sulit untuk mobilitas vertikal lewat pendidikan. Selain itu, di sekolah-sekolah pemerintah kala itu tidak diajarkan pendidikan agama, dengan alasan untuk menjamin kenetralan (Daulay, 2001: x) Kondisi ini mendorong terbentuknya organisasi-organisasi sosial keagamaan di Indonesia, yang salah satu bidang garapannya adalah dalam hal pendidikan.

Selanjutnya, di awal abad ke-20 muncul lembaga pendidikan baru yang bernama madrasah. Munculnya madrasah di Indonesia ketika itu tak terlepas dari pengaruh ide-ide pembaruan pemikiran Islam yang timbul di Indonesia pada awal abad ke-20. Sebagai sebuah lembaga yang muncul setelah pesantren dan sekolah maka nampaknya madrasah mengadopsi sistem pesantren dan sekolah sekaligus. Madrasah pada zaman kolonial Belanda telah berkembang di Indonesia tetapi belum terkoordinir dalam satu kesatuan diantara seluruh madrasah tersebut. Masing-masing madrasah muncul dengan caranya sendiri-sendiri. Setelah Indonesia merdeka madrasah berada di bawah naungan Departemen Agama, dan segala aturan mengenai ini di bawah kendali Departemen Agama (Daulay, 2001: xi).

Dalam perkembangannya pesantren, sekolah dan madrasah senantiasa melakukan inovasi dan juga transformasi dalam dirinya, baik dari isi (materi) yang diajarkan maupun dari metode serta managemennya dalam rangka menciptakan pendidikan yang lebih berkualitas sebagai tuntutan perubahan zaman. Perubahan-perubahan tersebut telah banyak menciptakan kemajuan baik dalam pesantren, sekolah ataupun madrasah. Namun berdasarkan beberapa referensi dan juga realitas di lapangan nampaknya masih banyak juga terdapat problematika yang dihadapi oleh lembaga-lembaga tersebut, baik problem dalam input, proses ataupun 
outputnya. Maka dalam artikel ini penulis akan membahas lebih jauh tentang problem mutu dan kualitas input-proses-output dalam pesantren, sekolah dan madrasah.

\section{Manajemen Pesantren, Sekolah dan Madrasah}

1. Manajemen Pesantren

a. Manajemen

Secara etimologis, kata "manajemen" berasal dari kata "managio", berarti "pengurusan" atau "managiare", yaitu melatih dalam mengatur langkah-langkah, atau dapat juga berarti bahwa manajemen sebagai ilmu, kiat dan profesi (Sagala, 2004: 13).

Ditinjau secara terminologi kata "manajemen" memiliki banyak makna. Beberapa pengertian manajemen dalam perspektif para pakar, antara lain sebagai berikut:

1. Kementerian Pendidikan Nasional memberikan definisi manajemen sebagai proses penggunaan sumber daya secara efektif untuk mencapai sasaran (Departemen Pendidikan dan Kebudayaan, 1997: 623).

2. Nanang Fattah dalam bukunya Landasan Manajemen Pendidikan memberikan batasan tentang istilah manajemen, yakni: manajemen merupakan proses merencana, mengorganisasi, memimpin dan mengendalikan upaya organisasi dengan segala aspeknya agar tujuan organisasi tercapai secara efektif dan efisien (Fattah, 2004: 1).

3. Tim Pakar Manajemen Pendidikan Universitas Negeri Malang mengartikan istilah manajemen sebagai berikut: $\mathrm{Ma}-$ najemen dapat diartikan sebagai tindakan untuk mencapai tujuan melalui usaha-usaha orang lain. Seorang kepala SMA dapat diartikan melakukan aktivitas manajemen, manakala berupaya mengatur guru-guru dan karyawan, mendayagunakan dan melakukan pembinaan terhadap mereka sehingga mampu berpartisipasi sepenuhnya untuk mencapai tujuan pendidikan di sekolah (Tim Pakar Manjemen Pendidikan UNY, 2002: 5). 
Dari berbagai penjelasan di atas dapat disimpulkan, bahwa manajemen adalah suatu ilmu atau seni yang dimiliki oleh seorang pemimpin (leader) dalam upaya memanfaatkan sumber-sumber daya organisasi yang ada melalui kegiatan perencanaan, pengorganisasian, pelaksanaan dan pengawasan serta dilakukan dengan melibatkan partisipasi seluruh komponen menurut fungsinya masing-masing dalam rangka mencapai tujuan organisasi secara efektif dan efisien.

b. Pesantren

Perkataan pesantren berasal dari kata santri, dengan awalan pe dan akhiran an yang berarti tempat tinggal santri (Dhofier, 1994: 18). Dengan nada yang sama Soegarda Poerbakawatja sebagaimana yang dikutip oleh Haidar Putra Daulay menjelaskan pesantren asal katanya adalah santri, yaitu seorang yang belajar agama Islam, sehingga dengan demikian pesantren mempunyai arti tempat orang berkumpul untuk belajar agama Islam (Daulay, 2009: 61).

Apa sebetulnya persyaratan-persyaratan pokok suatu lembaga pendidikan baru dapat digolongkan sebagai pesantren. Untuk perlu dilihat apabila telah mencukupi elemen-elemen pokok pesantren. Elemen-elemen pokok pesantren itu adalah: pondok, masjid, santri, pengajaran kitab-kitab klasik dan kyai (Dhofier, 1994: 44).

Dari sekian banyak pesantren dapat dipolakan secara garis besar kepada dua pola. Pertama berdasarkan bangunan fisik, kedua berdasarkan kurikulum. Berdasarkan bangunan fisik dapat dipolakan sebagai berikut:

\begin{tabular}{|l|l|}
\multicolumn{1}{|c|}{ Pola I } & \multicolumn{1}{|c|}{ Keterangan } \\
Masjid & $\begin{array}{l}\text { Pesantren ini masih bersifat sederhana, } \\
\text { Rumah Kyai }\end{array}$ \\
& $\begin{array}{l}\text { dimana kyai menggunakan masjid atau } \\
\text { Dalam pola ini santri hanya datang dari } \\
\text { daerah itu sendiri, namun mereka telah } \\
\text { mempelajari ilmu agama secara kontinu dan } \\
\text { sistematis. Metode pengajaran: wetonan dan } \\
\text { sorogan. }\end{array}$ \\
\hline
\end{tabular}




\begin{tabular}{|c|c|}
\hline Pola II & Keterangan \\
\hline $\begin{array}{l}\text { Masjid } \\
\text { Rumah Kyai } \\
\text { Pondok }\end{array}$ & $\begin{array}{l}\text { Dalam pola ini pesantren talah memiliki } \\
\text { pondok atau asrama yang disediakan bagi } \\
\text { para santri yang datang dari daerah. Metode } \\
\text { pengajaran: wetonan dan sorogan. }\end{array}$ \\
\hline Pola III & Keterangan \\
\hline $\begin{array}{l}\text { Masjid } \\
\text { Rumah Kyai } \\
\text { Pondok } \\
\text { Madrasah }\end{array}$ & $\begin{array}{l}\text { Pesantren ini telah memakai sistem klasikal, } \\
\text { dimana santri yang mondok mendapat } \\
\text { pendidikan di madrasah. Ada kalanya murid } \\
\text { madrasah itu datang dari daerah sekitar } \\
\text { pesantren itu sendiri. Di samping sistem } \\
\text { klasikal juga pengajaran sistem wetonan } \\
\text { dilakukan oleh kyai. }\end{array}$ \\
\hline Pola IV & Keterangan \\
\hline $\begin{array}{l}\text { Masjid, Rumah } \\
\text { Kyai, Pondok, } \\
\text { Madrasah, Tempat } \\
\text { keterampilan }\end{array}$ & $\begin{array}{l}\text { Dalam pola ini di samping memiliki madrasah } \\
\text { juga memiliki tempat-tempat keterampilan. } \\
\text { Misalnya peternakan, pertanian, kerajinan } \\
\text { rakyat, toko, koperasi dan sebagainya. }\end{array}$ \\
\hline Pola V & Keterangan \\
\hline $\begin{array}{l}\text { Masjid, Rumah } \\
\text { Kyai, Pondok, } \\
\text { Madrasah, Tempat } \\
\text { keterampilan, } \\
\text { Universitas, } \\
\text { Gedung } \\
\text { pertemuan, Tempat } \\
\text { olahraga, Sekolah } \\
\text { umum }\end{array}$ & $\begin{array}{l}\text { Dalam pola ini pesantren yang sudah } \\
\text { berkembang dan bias digolongkan pesantren } \\
\text { mandiri. Pesantren seperti ini telah memiliki } \\
\text { perpustakaan, dapur umum, ruang makan, } \\
\text { kantor administrasi, took, rumah penginapan } \\
\text { tamu, ruang operating room dan sebagainya. } \\
\text { Di samping itu pesantren juga mengelola } \\
\text { SMP, SMA dan kejuruan lainnya. }\end{array}$ \\
\hline
\end{tabular}

Table 1. Pola Pendidikan Pesantren Berdasarkan Bangunan Fisik

Sedangkan pembagian pola pesantren berdasarkan kurikulumnya dapat dipolakan menjadi lima, yaitu:

Pola I, materi pelajaran yang dikemukakan di pesantren ini adalah mata pelajaran agama yang bersumber dari kitab-kitab klasik. Metode penyampaiannya adalah wetonan dan sorogan, tidak memakai sistem klasikal. Santri dinilai dan diukur berdasarkan 
kitab yang dibaca. Mata pelajaran umum tidak diajarkan, tidak mementingkan ijazah sebagai alat untuk mencari kerja. Yang paling dipentingkan adalah pendalaman ilmu-ilmu agama semata-mata melalui litab-kitab klasik.

Pola II, pola ini hampir sama dengan pola I di atas, hanya saja pada pola II proses belajar mengajar dilaksanakan secara klasikal dan non klasikal, juga dididikkan keterampilan dan pendidikan berorganisasi. Pada tingkat tertentu diberikan sedikit pengetahuan umum. Santri dibagi jenjang pendidikannya mulai tingkat ibtidaiyah, tsanawiyah dan aliyah. Metode: wetonan, sorogan, hafalan dan musyawarah.

Pola III, pada pola ini materi pelajaran telah dilengkapi dengan mata pelajaran umum, dan ditambah pula dengan memberikan aneka macam pendidikan lainnya. Seperti keterampilan, kepramukaan, olahraga, kesenian dan pendidikan berorganisasi, dan sebagian telah melaksanakan program pengembangan masyarakat.

Pola IV, pola ini menitikberatkan pelajaran keterampilan di samping pelajaran agama. Keterampilan ditujujan untuk bekal kehidupan bagi seorang santri setelah tamat dari pesantren ini. Keterampilan yang diberikan meliputi pertanian, pertukangan dan peternakan.

Pola V, pada pola ini materi yang diajarkan di pesantren adalah sebagai berikut:

1. Pengajaran kitab-kitab klasik.

2. Madrasah, di pesantren ini diadakan pendidikan model madrasah, selain mengajarkan mata pelajaran agama, juga mengajarkan mata pelajaran umum. Kurikulum madrasah pondok dapat dibagi kepada dua bagian, pertama kurikulum yang dibuat oleh pondok sendiri dan kedua kurikulum pemerintah dengan memodifikasi materi pelajaran agama.

3. Keterampilan juga diajarkan berbagai bentuk kegiatan keterampilan.

4. Sekolah umum, di pesantren dilengkapi dengan sekolah umum. Sekolah umum yang ada di pesantren materi 
pelajaran umum seluruhnya berpedoman kepada kurikulum Kemendikbud. Sedangkan materi pelajaran agama disusun oleh pondok sendiri. Diluar kurikulum pendidikan agama yang diajarkan di sekolah, pada waktu-waktu yang sudah terjadwal santri menerima pendidikan agama lewat membaca kitab-kitab klasik.

5. Perguruan tinggi, pada beberapa pesantren yang tergolong pesantren besar telah membuka universitas atau perguruan tinggi (Daulay, 2009: 65).

Selanjutnya bila uraian mengenai manajemen dilihat praktenya di pesantren, maka pembahasan ini tidak akan terlepas dari polapola manajemen yang telah diterapkan di pesantren sebagaimana disebutkan di atas. Manajemen pesantren dalam arti pengelolaan pesantren dapat dimaknai sebagai sebuah proses menggerakkan sumber daya yang ada di pesantren untuk mencapai tujuan. Tujuan pesantren menurut Mastuhu sebagaimana yang dikutip oleh Syamsudduha adalah: menciptakan dan mengembangkan kepribadian muslim, yaitu kepribadian yang beriman dan bertaqwa kepada Tuhan, berakhlak mulia, bermanfaat bagi masyarakat dengan jalan menjadi abdi masyarakat berdasarkan sunah Rasul, mampu berdiri sendiri, bebas dan tegas dalam kepribadian, menyebarkan agama atau menegakkan Islam dan kejayaan umat Islam di tengah-tengah masyarakat, serta mencintai ilmu dalam rangka mengembangkan kepribadian Indonesia (Syamsudduha, 2004: 34).

Untuk mewujudkan tujuan di atas diperlukan suatu upaya pengelolaan sumber daya organisasi pesantren. Sumber daya organisasi yang dimaksud antara lain: manusia (kyai, ustadz, pembina, pengelola, santri), uang, sarana/prasarana (masjid, ruang kelas, pondok, kurikulum), dan informasi (Syamsudduha, 2004: 35). Dalam pengelolaan sumber daya organisasi inilah perlu diterapkan teori-teori manajemen professional, untuk mewujudkan pendidikan pesantren yang lebih berkualitas.

\section{Manajemen Sekolah}

Dalam Kamus Umum Bahasa Indonesia sekolah mempunyai beberapa arti sebagai berikut: 
a. Bangunan atau lembaga untuk belajar dan memberi pelajaran.

b. Waktu atau pertemuan ketika murid-murid diberi pelajaran.

c. Usaha menuntut kepandaian (ilmu pengetahuan) (Poerwadarminta, 1976: 889).

Dalam buku-buku mengenai teori pendidikan, dijelaskan bahwa sekolah merupakan salah satu dari tripusat pendidikan, di samping rumah tangga dan masyarakat. Walaupun ketiganya dikelompokkan kepada lingkungan pendidikan, namun dari segi-segi teknis pelaksanaan pendidikan terdapat perbedaan antara satu dengan yang lainnya (Daulay, 2001: 35).

Sekolah menitikberatkan pendidikan formal, prosedur pendidikannya telah diatur sedemikian rupa, ada guru, ada siswa, ada jadwal pelajaran yang berpedoman kepada kurikulum, silabus dan GBPP (Garis-Garis Besar Program Pengajaran), ada jam-jam tertentu waktu belajar serta dilengkapi dengan sarana dan fasilitas pendidikan, baik perangkat keras maupun perangkat lunak.

Lingkungan masyarakat menitikberatkan kepada pendidikan non formal, sedangkan lingkungan rumah tangga lebih berorientasi kepada pendidikan informal.

Menurut Barnadib sebagaimana yang telah dikutip oleh Daulay bahwa sekolah pada hakikatnya bertujuan untuk membantu orang tua mengajarkan kebiasaan-kebiasaan baik dan menanamkan budi pekerti yang baik, juga diberikan bekal kehidupan dalam masyarakat yang sukar diperoleh dalam rumah tangga (Daulay, 2001: 36).

Dengan demikian sebenarnya pendidikan di sekolah adalah bagian dari pendidikan dalam keluarga, yang sekaligus juga merupakan lanjutan dari pendidikan dalam keluarga. Disamping itu, kehidupan di sekolah merupakan jembatan bagi anak untuk menghubungkan kehidupan dalam keluarga dengan kehidupan dalam masyarakat.

Pengertian sekolah yang dimaksud dalam tulisan ini adalah lembaga pendidikan formal yang menekankan inti pelajaran kepada pelajaran umum, bukan mata pelajaran agama, sebagaimana yang terdapat di pesantren dan madrasah.

Dalam operasionalnya di sekolah, manajemen dapat dilihat sebagai gugusan-gugusan tertentu. Gugusan-gugusan ini selanjutnya boleh disebut 
bidang garapan manajemen pendidikan. Menurut Mulyasa sebagaimana yang dikutip oleh Jaja Jahari terdapat tujuh komponen sekolah yang merupakan garapan penting dari manajemen sekolah, antara lain:

a. Manajemen kesiswaan/peserta didik

b. Manajemen tenaga pendidik dan kependidikan

c. Manajemen kurikulum dan program pengajaran

d. Manajemen keuangan/pembiayaan

e. Manajemen sarana dan prasarana pendidikan

f. Manajemen hubungan sekolah dan masyarakat

g. Manajemen layanan khusus (Syarbini, 2013: 13).

Baik dan buruknya pengelolaan terhadap tujuh komponen pendidikan di atas akan menentukan kualitas suatu lembaga pendidikan, baik kualitas input, proses ataupun outputnya. Selain pengelolaan yang bagus tentunya semua itu harus didukung dengan kepemimpinan yang professional pula.

\section{Manajemen Madrasah}

Kata "madrasah" dalam bahasa Arab adalah bentuk kata keterangan tempat (dzaraf makan) dari akar kata "darasa". Secara harfiah "madrasah" diartikan sebagai "tempat belajar para pelajar", atau "tempat untuk memberikan pelajaran”. Dari akar kata "darasa" juga bisa diturunkan kata "midras" yang mempunyai arti "buku yang dipelajari" atau "tempat belajar" (Syarbini, 2013: 3).

Pengertian madrasah menurut Kemenag sebagaimana yang dikutip oleh Haidar adalah sebagai berikut:

1. Menurut Peraturan Menteri Agama RI No. 1 Tahun 1946 dan Peraturan Menteri Agama RI No. 7 Tahun 1950, madrasah mangandung makna:

a. Tempat pendidikan yang diatur sebagai sekolah dan membuat pendidikan dan ilmu pengetahuan agama Islam, menjadi pokok pengajaran.

b. Pondok dan pesantren yang memberi pendidikan setingkat dengan madrasah.

2. Menurut Surat Keputusan Bersama Tiga Menteri Tahun 1975, menjelaskan pengertian madrasah adalah: Lembaga pendidikan 
yang menjadikan mata pelajaran agama Islam sebagai mata pelajaran dasar yang diberikan sekurang-kurangnya 30\% di samping mata pelajaran umum (Daulay, 2001: 61).

Di dunia pesantren terkenal adanya unsur-unsur pokok dari pesantren, yaitu kyai, santri, pondok, masjid dan pengajaran mata pelajaran agama Islam. Pada sistem madrasah tidak harus ada pondok, masjid, dan pengajian kitab-kitab klasik. Unsur-unsur yang diutamakan di madrasah adalah pimpinan, guru, siswa, perangkat keras, perangkat lunak dan pengajaran mata pelajaran agama Islam (Daulay, 2001: 59).

Abdul Hafis Dasuki mengemukakan perbedaan antara madrasah dan pesantren sebagaimana yang dikutip oleh Haidar adalah sebagai berikut:

... it is the madrasa, rather than in the pondok pesantren, that the more modern ideas on education and schooling have generally had the most influence. The madrasa is more like a western - style school than is the pondok pesantren with its dormitory arrangement and traditional, unregulated way of study (Daulay, 2001: 60).

Perbedaan-perbedaan antara madrasah dan pesantren seperti yang dikutip di atas adalah antara madrasah dan pesantren tradisional, atau dalam pengklasifikasian pesantren sebagaimana yang telah di sebutkan di depan tergolong pesantren pola I. Adapun terhadap pola lain tidaklah demikian halnya.

Perbedaan yang tepat antara madrasah dan pondok pesantren secara keseluruhan berangkat dari unsur-unsur pesantren yang telah disebutkan di depan. Sebab bila berangkat dari metode pengajaran, materi yang diajarkan dan kehadiran, maka saat sekarang ini telah banyak pesantren yang memiliki cara yang sama dengan madrasah, seperti pesantren pola II, III, IV dan V.

Sebenarnya sistem madrasah mirip dengan sistem sekolah umum di Indonesia, para siswa tidak diharuskan tinggal mondok di kompleks madrasah. Siswa cukup datang ke madrasah pada jam-jam berlangsungnya pelajaran pada pagi atau sore hari. Dan juga tidak disyaratan adanya masjid di lingkungan madrasah, kalaupun siswa bermaksud melaksanakan sholat, mereka melaksanakan di ruang yang telah ditentukan untuk itu. Kyai pun, sebagai orang yang sangat dihormati tidak mesti ada, cukup pimpinan 
madrasah dan aparat-aparatnya. Pengajian kitab-kitab klasik pun tidak mesti ada di madrasah. Pelajaran-pelajaran yang akan diajarkan telah tercantum dalam kurikulum dan silabus, dan diuraikan dalam GBPP (Daulay, 2001: 60).

Ditinjau dari segi jenis madrasah berdasarkan kurikulumnya dapat dibagi menjadi tiga jenis. Pertama, Madrasah Diniyah. Kedua, Madrasah dan ketiga, Madrasah Keagamaan. Madrasah Diniyah adalah suatu bentuk madrasah yang hanya mengajarkan ilmu-ilmu agama (diniyah). Madrasah ini dimaksudkan sebagai lembaga pendidikan agama yang disediakan bagi siswa yang belajar di sekolah umum. Madrasah ini terbagi menjadi tiga jenjang pendidikan:

1. Madrasah Diniyah Awaliyah untuk siswa-siswi Sekolah Dasar (4 tahun).

2. Madrasah Diniyah Wustho untuk siswa-siswi Sekolah Lanjutan Pertama (3 tahun).

3. Madrasah Diniyah 'Ulya untuk siswa-siswi Sekolah Lanjutan Atas (3 tahun).

Madrasah jenis kedua adalah madrasah, sekolah yang berciri khas agama Islam. Madrasah ini terdiri dari tingkatan Madrasah Ibtidaiyah, Madrasah Tsanawiyah dan Madrasah Aliyah. Programnya sama dengan sekolah, hanya saja diberikan bobot pendidikan agama yang lebih banyak dibanding dengan sekolah negeri. Sedangkan madrasah jenis ketiga adalah madrasah keagamaan, yakni madrasah pada jenjang pendidikan menengah yang mengutamakan penguasaan pengetahuan khusus siswa tentang ajaran agama yang bersangkutan (Daulay, 2001: 62).

Penerapan manajemen dalam madrasah akan mancakup tujuh komponen madrasah sebagaimana yang terdapat dalam sekolah. Selain tujuh komponen di atas Mansur Muslich menambahkan enam komponen lain dari komponen sekolah/madrasah yang masuk dalam garapan manajemen madrasah sebagaiamana yang dikutip oleh Jaja Jahari, yaitu: mutu madrasah, kepemimpinan madrasah, kebijakan madrasah, inovasi madrasah, supervisi madrasah, dan pemasaran jasa pendidikan pada madrasah (Syarbini, 2013: 15). Baik dan buruknya pengelolaan terhadap komponen-komponen madrasah di atas juga akan mempengaruhi kualitas input, proses dan output dalam madrasah. 


\section{Problematika Mutu dan Kualitas Input-Proses-Output di Pesantren, Sekolah dan Madrasah}

Sebelum menjelaskan lebih jauh mengenai problematika pendidikan yang terjadi di pesantren, sekolah dan madrasah sekiranya perlu diketahui dulu bahwa pendidikan sebagai sebuah sistem terdiri dari sejumlah komponen. Sistem-sistem tersebut terdiri atas instrumental input, raw input, input, process, output, environmental, dan outcomes. Masing-masing komponen mempunyai fungsi tertentu dan secara bersama-sama melaksanakan fungsi struktur, yaitu mencapai tujuan system (Apip, komponen-komponen dalam sistem pendidikan. www://apip 0103. Blogspot. Com [2 Oktober 2014]). Namun pada pembahasan ini, komponen-komponen tersebut diidentifikasikan pada sistem pendidikan yang berupa input, proses dan output.

Input pada sistem pendidikan dibedakan dalam tiga jenis, yaitu input mentah (raw input), input alat (instrumental input), dan input lingkungan (environmental input). Masukan mentah (raw input) akan diproses menjadi tamatan (output) dan input pokok dalam sistem pendidikan adalah dasar pendidikan, tujuan pendidikan, dan anak didik atau peserta didik.

Sedangkan proses pendidikan merupakan kegiatan mobilisasi segenap komponen pendidikan oleh pendidik terarah kepada pencapaian tujuan pendidikan. Kualitas proses pendidikan menggejala pada dua segi, yaitu kualitas komponen dan kualitas pengelolaannya. Kedua segi tersebut satu sama lain saling bergantung. Adapun komponen-komponen yang saling berkesinambungan pada proses pendidikan meliputi: pendidik dan non pendidik, kurikulum (materi pendidikan), prasarana dan sarana, administrasi, dan anggaran.

Kemudian yang terakhir output pada sistem pendidikan adalah hasil keluaran dari proses yang terjadi di dalam sistem pendidikan. Adapun output pada sistem pendidikan adalah: lulusan (tamatan) dan putus sekolah. 


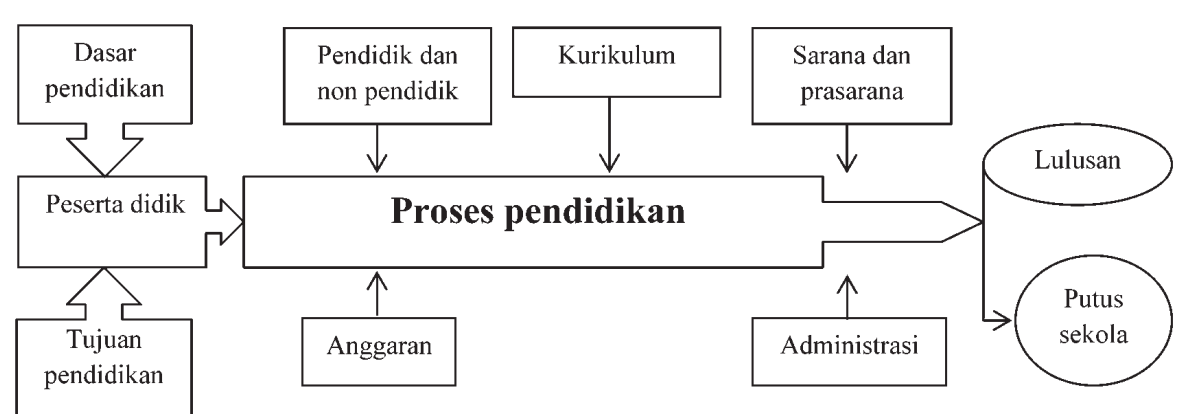

Gambar 1. Komponen-Komponen dalam Sistem Pendidikan

\section{Problem di Pesantren}

Lembaga pendidikan Islam yang paling variatif adalah pesantren, mengingat adanya kebebasan dari kyai pendirinya untuk mewarnai pesantrennya itu dengan penekanan pada bidang tertentu. Misalnya ada pesantren ilmu alat, pesantren fikih, pesantren al-Qur'an, pesantren hadis dan juga pesantren tasawuf. Masing-masing pengkhususan dalam bidang tersebut didasarkan pada keahlian kyai pengasuhnya.

Ditinjau dari segi keterbukaan terhadap perubahan-perubahan yang terjadi dari luar, pesantren dapat dibagi dua: pesantren tradisional (salafi) dan pesantren modern (khalafi). Pesantren salafi bersifat konservatif, sedangkan pesantren khalafi bersifat adaptif. Adaptasi dilakukan terhadap perubahan dan pengembangan pendidikan yang merupakan akibat dari tuntunan perkembangan sains dan teknologi modern (Qomar, 2007: 58).

Perbedaan antara pesantren tradisional dengan pesantren modern dapat dilihat dari perspektif manajerialnya. Secara umum pesantren tradisional dikelola tanpa menggunakan kaidah-kaidah manajerial yang berlaku sehingga berjalan apa adanya. Sedangkan pesantren modern dikelola dengan rapi menggunakan kaidah-kaidah manajemen yang berlaku. Oleh karena itu, pembahasan tentang problematika pesantren dalam artikel ini diarahkan terhadap pesantren tradisional yang mempunyai tantangan multidimensi. Hal ini merupakan hasil generalisasi, artinya merupakan penarikan kesimpulan umum, tanpa memperhatikan pengecualian-pengecualian yang ada.

Diantara problem input yang terdapat dalam pesantren adalah lemahnya visi dan tujuan yang dibawa pendidikan pesantren, hal ini menyebabkan pesantren tidak mampu mengikuti dan menguasai 
perkembangan zaman. Relatif sedikit pesantren yang mampu secara sadar merumuskan tujuan pendidikan serta menuangkannya dalam tahapantahapan rencana kerja atau program. Kondisi ini menurut Nurcholish Madjid sebagaimana yang dikutip oleh Yasmadi lebih disebabkan adanya kecenderungan visi dan tujuan pesantren diserahkan pada proses improvisasi yang dipilih sendiri oleh seorang kyai atau bersama-sama para pembantunya (Yasmadi, 2007: 72).

Akibatnya hampir semua pesantren dalam pandangan Nurcholish Madjid merupakan hasil usaha pribadi atau individual (individual enterprise), karena dari pancaran kepribadian pendirinyalah dinamika pesantren itu akan terlihat. Dalam hal ini Nurcholish Madjid mengemukakan, pada dasarnya memang pesantren itu sendiri dalam semangatnya adalah pancaran kepribadian pendirinya (Yasmadi, 2002: 73).

Kritikan yang lain juga dilontarkan oleh Zamakhsyari Dhofier, ia mensinyalir bahwa kebanyakan kyai di Jawa beranggapan bahwa suatu pesantren dapat diibaratkan sebagai suatu kerajaan kecil dimana kyai merupakan sumber mutlak dari kekuasaan dan kewenangan (power and authority) dalam kehidupan dan lingkungan pesantren (Dhofier, 1994: 56). $\mathrm{Hal}$ ini menjadikan cukup logis bila dikatakan bahwa penentu arah dan tujuan kebijakan pendidikan pesantren berada pada kekuasaan otoritas kyai. Kondisi nyatapun juga demikian hampir tidak ada rumusan tertulis tentang kurikulum, tujuan dan sasaran pendidikan pesantren, kecuali hanya terapaku pada otoritas kyai.

Problem kualitas input pesantren selanjutnya dapat dilihat dari kondisi peserta didik atau dalam hal ini santri sebagai penghuni pesantren. Keseharian para santri ini ternyata memberikan fenomena menarik bila dibandingkan dengan kehidupan di luar pesantren. Untuk lebih jelasnya berikut ini pemaparan kondisi nyata para santri mulai dari pakaian, kondisi kesehatan, perilaku, dan penyimpangan-penyimpangan yang mungkin mereka lakukan:

a. Pakaian: bukannya karena mereka adalah "kaum sarungan" (ejekan Hadi Subeno almarhum), tetapi cara memakainya yang penting. Umumnya para santri tidak membedakan antara pakaian untuk belajar, dalam kamar, keluar pondok pesantren, bahkan untuk tidur pun tidak berbeda. 
b. Kesehatan: penyakit yang biasanya diasosiasikan dengan para santri adalah penyakit kudis (gudigen dalam bahasa jawa). Meskipun sekarang ini sudah jarang kelihatan, tetapi kondisi yang "favourable" untuk penyakit kulit itu masih banyak terdapat di pesantren.

c. Tingkah laku: sudah menjadi rahasia umum bahwa para santri mengidap penyakit rasa rendah diri dalam pergaulan ketika harus berasosiasi dengan masyarakat di luar mereka.

d. Salah satu hal yang bisa sangat mengejutkan peninjau dari luar adalah adanya suatu praktek di kalangan para penghuni pondok, meskipun ini jarang terjadi, yang justru sangat bertentangan dengan ajaran moral agama sendiri. Praktek itu agaknya merupakan akibat buruk dari sistem asrama yang tidak membenarkan pergaulan (sekedar pergaulan saja!) dengan jenis kelamin lain. Praktek yang pernah dilakukan oleh kaum Nabi Luth dan yang dalam al-Qur'an mendapatkan kutukan Tuhan ini justru di pesantren (tidak semua pesantren) hampir dianggap sebagai "taken for granted" (Madjid, 1997: 92).

Selanjutnya terkait proses pendidikan di pesantren juga masih terdapat berbagai permasalahan yang dihadapai, diantaranya mengenai kurikulum, metode pembelajaran, sarana prasarana dan administrasi. Permasalahan kurikulum di pesantren terkait dengan pemberian pelajaran umum yang tidak efektif. Barangkali sekarang ini praktis semua pesantren mengajarkan ilmu pengetahuan umum. Tetapi tampaknya dilaksanakan secara setengah-setengah, sekedar memenuhi syarat atau agar tidak dinamakan kolot saja. Sehingga kemampuan santri pun biasanya sangat terbatas dan kurang mendapat pengakuan masyarakat umum (Madjid, 1997: 94).

Kelemahan pendidikan pesantren yang lain adalah suasana pembelajaran yang pasif.(Qomar,2007:73). Hal ini masih banyak dijumpai di pesantren yang salah satu sebabnya adalah minimnya kreativitas dan juga inovasi guru terhadap pengembangan metodologi pembelajaran aktif, sehingga membuat daya kritis santri menjadi lemah. Maka agar nalar kritis tumbuh di pesantren, para pendidiknya harus mau melakukan formulasi pola pendidikan dengan menyertakan metodologi modern.

Selanjutnya rendahnya mutu sarana dan prasarana di pesantren dapat diketahui dari paparan Nurcholish Madjid berikut ini: 
a. Pengaturan "tata kota" -Istilah ini dipinjam dari planologi kotapesantren memiliki ciri yang khas, yaitu letak masjid, asrama atau pondok, madrasah, kamar mandi, kakus (WC) umum, perumahan pimpinan, dan lain-lain umumnya sporadis.

b. Kamar-kamar asramanya sempit, terlalu pendek, jendela terlalu kecil, dan pengaturannya pun sremawut. Selain itu minim peralatan, seperti dipan, meja kursi, dan tempat untuk menyimpan pakaian.

c. Jumlah kamar mandi dan kakus (WC) tidak sebanding dengan banyaknya jumlah santri yang ada. Atau malah ada pesantren yang tidak menyediakan fasilitas ini sehingga para santrinya mandi dan buang air di sungai. Kalaupun ada kondisinya tidak memenuhi syarat sistem sanitasi yang sehat.

d. Madrasah atau ruang kelas yang digunakan tidak memenuhi persyaratan metodik-didaktik atau ilmu pendidikan yang semestinya, seperti ukuran yang terlalu sempit atau terlalu luas. Antara dua ruang kelas tidak dipisahkan oleh suatu penyekat, ataupun kalau ada penyekatnya tidak tahan suara sehingga gaduh. Perabotannnya yang berupa bangku, papan tulis, dan lain-lain juga kurang mencukupi baik dari segi kualitas maupun kuantitasnya.

e. Tempat ibadah (masjid/musholla) pada umumnya keadaannya juga mengecewakan: kebersihan lantainya kurang terjaga-ini ada hubungannya dengan sistem penyediaan air wudhu/kolam-, arsitektur bangunan dan pembagian ruangannya tidak menunjukkan efesiensi dan kerapian, kurangnya sistem penerangan dan lain-lain (Madjid, 1997: 91).

Dalam hal administrasi pesantren menganut pola "serba mono", sehingga tidak ada delegasi kewenangan ke unit-unit kerja lain yang ada dalam organisasi. Disamping itu, masih ada kebiasaan pendidikan pesantren yang menerapkan manajemen "serba informal". Pola serba mono dan serba informal itu ternyata memiliki hubungan yang erat sekali. Kebiasaan pengelolaan serba mono dengan kebijakan yang terpusat hanya pada kyai mengakibatkan mekanisme formal tidak berlaku lagi, sementara keputusan-keputusan kyai bersifat deterministik dan keharusan untuk dijalankan (Qomar, 2007: 60). Oleh karena itu, pesantren harus segera membenahi dirinya dengan menerapkan kaidah-kaidah manajemen yang berlaku dalam rangka optimalisasi administrasi dalam pesantren. 
Pembahasan yang terakhir dari pesantren adalah mengenai problem kualitas outputnya, disini ada beberapa pembacaan dari Nurcholish Madjid mengenai hal tersebut, diantaranya sebagai berikut:

a. Para alumni pesantren hanya cocok terutama untuk jenis masyarakat yang memang sudah dari semula menerima dan mengadopsi nilainilai yang ada di pesantren yang bersangkutan. Sedangkan untuk masyarakat umum, mereka kurang memenuhi harapan.

b. Lebih ironis lagi jika keadaan para alumni pesantren ini dihubungkan dengan slogan yang merupakan slogan favoritnya para santri, yaitu tidak mau menjadi pegawai negeri. Agaknya slogan ini merupakan sisa sikap isolatif dan non-kooperatif zaman kolonial Belanda dulu. Tetapi sekarang perlu diperiksa kembali apakah slogan itu merupakan sikap hasil perenungan yang sadar ataukah sekedar seperti kata pepatah “anggurnya masam” saja. Maksudnya tidak mau menjadi pegawai negeri sebab mereka memang tidak memenuhi syarat untuk jadi pegawai negeri.

c. Salah satu yang diharapkan dari pesantren, jadi juga dari para alumninya adalah agar berpartisipasi dalam pembangunan, khususnya pembangunan masyarakat. Dalam berpartisipasi ini tidak saja diperlukan ketrampilan dan pengetahuan dasar, tetapi juga kesadaran untuk menerima tanggung jawab pribadi terhadap masyarakat. Selain itu,para alumni ini dituntut memiliki kesupelan dalam membina hubungan antar manusia (buman relation) termasuk kemampuan membina kerja sama dengan orang lain. Sayangnya syarat-syarat ini kurang dimiliki para alumni pesantren (Madjid, 1997: 96).

\section{Problem di Sekolah}

Sekolah merupakan lembaga pendidikan formal yang menekankan inti pelajaran kepada pelajaran umum. Sebagian besar sekolah umum statusnya sudah negeri sehingga sudah tidak terdapat masalah dalam segi pendanaannya. Selain itu pengelolaan lembaganya sudah menggunakan manajemen yang professional, sebagimana yang dikemukakan oleh Budianto:

"Kebanyakan sekolah umum di Indonesia statusnya sudah negeri sehingga secara pendanaan sebagian besar sudah tercukupi. 
Dengan besarnya pendanaan ini maka sarana dan prasarana sekolah juga bisa diberikan secara lengkap. Selain itu pengelolaan lembaganya sudah menggunakan kaidah-kaidah manajemen yang berlaku sehingga unit-unit kerja yang ada di sekolah umum sudah tertata rapi” (Wawancara dengan Budianto, GPAI di SMA Slahung Ponorogo dan kepala sekolah SMP IT Thoriqul Huda Ponorogo [8 Oktober 2014]).

Kondisi yang demikian bukan berarti di sekolah umum berjalan tanpa adanya masalah, hanya saja permasalahan yang ada tidak terjadi sebanyak di pesantren ataupun madrasah. Permasalahan yang masih sering muncul di sekolah biasanya terkait masalah klasik mengenai kualitas pendidiknya dan juga masalah yang baru muncul terkait implementasi kurikulum 2013 yang disinyalir juga terdapat permasalahan yang sama pada lembaga yang lainnya, sebagaimana penuturan Budianto berikut ini:

"Di sekolah umum masih banyak ditemukan guru yang mengajar tanpa melengkapi perangkat pembelajaran yang dibutuhkan dan juga masih menggunakan metode konvesional. Selain itu terkait penerapan kurikulum 2013 banyak guru yang belum bisa menerapkan model pembelajaran berupa tematik-integratif, pendekatan saintifik, strategi aktif dan juga masih kesulitan dalam menerapkan penilaian autentik" (Wawancara dengan Budianto, GPAI di SMA Slahung Ponorogo dan kepala sekolah SMP IT Thoriqul Huda Ponorogo [8 Oktober 2014]).

Berkaitan dengan mutu lulusan dari sekolah secara umum mereka kurang matang dalam pemahaman keagamaan, karena memang porsi jam mata pelajaran agama mereka sangat terbatas. Oleh karena itu, sekolah harus juga mengupayakan kegiatan-kegiatan ektra di luar kelas yang bersifat agamis sehingga membantu siswa dalam peningkatan spiritualitasnya. Selain itu kualifikasi lulusan sekolah umum terhadap jurusan yang mereka ambil, belum tentu lebih baik dari lulusan madrasah, karena faktor individu peserta didik juga sangat berpengaruh terhadap hasil pencapaiannya.

\section{Problem di Madrasah}

Madrasah selama ini dianggap sebagai lembaga pendidikan Islam yang mutunya lebih rendah daripada mutu lembaga pendidikan 
lainnya, terutama sekolah umum, walaupun beberapa madrasah justru lebih maju daripada sekolah umum. Namun, keberhasilan beberapa madrasah dalam jumlah yang terbatas itu belum mampu menghapus kesan negatif yang sudah terlanjur melekat.

Sebagian besar madrasah di Indonesia berstatus swasta, yakni sebesar 85\% berdasarkan data statistik kementerian Agama tahun 2008/2009 (Deskriptif Statistik Pendidikan Madrasah. www://pendis.kemenag.go.id [5 Oktober 2014]). Dengan statusnya itu madrasah selalu saja mengalami serba kekurangan, misalnya guru yang mengajar belum tentu memperoleh imbalan kesejahteraan yang cukup, buku-buku belum tentu tersedia dan apalagi sarana dan prasarana lainnya.

Berkaitan dengan kualitas peserta didik di madrasah juga belum menguntungkan, potensi siswa madrasah rata-rata merupakan kelas menengah ke bawah. Secara intelektual kemampuan mereka lemah, sebab biasanya siswa yang memiliki prestasi baik cenderung melanjutkan ke sekolah umum. Secara ekonomi, posisi mereka juga berada pada kelas menengah ke bawah. Demikian juga secara sosial, mereka berasal dari kalangan masyarakat biasa (grass root) (Qomar, 2007: 84). Kondisi ini juga merupakan problem tersendiri bagi madrasah karena akan berpengaruh dalam proses pendidikan.

Sedangkan permasalahan dalam proses pendidikan di madrasah dirasakan juga begitu komplek, diantaranya terkait kualitas pendidik dan non pendidiknya, kurikulum, sarana dan prasarana, dan pendanaan. Terkait kondisi pendidik dan non pendidiknya, pada madrasah negeri maupun swasta belum begitu mengembirakan. Berdasarkan data bahwa, sebagian besar guru madrasah berasal dari IAIN/STAIN/ PTAIS. Padahal mata pelajaran pada madrasah banyak yang bersifat umum. Akibatnya para guru mengajar tidak sesuai dengan kualifikasi pendidikan yang dibutuhkan. Demikian juga kepala madrasah, masih banyak yang belum menjalankan tugas dan fungsinya dengan baik. Juga karyawannya, masih belum dapat menjalankan tugas dan fungsinya dengan baik, karena tidak didukung dengan professionalisme yang tinggi (Maimun dan Fitri, 2010: 7). Kondisi ini nantinya akan berdampak pada kualitas siswa madrasah yang tidak maksimal antara kualitas intelektual dan spiritualnya. 
Sedangkan keberadaan kurikulum di madrasah terlihat belum fokus. Hal ini terlihat misalnya banyaknya materi yang diajarkan sementara waktunya tidak memadai atau bahkan overload pada tingkat Aliyah, misalnya siswa yang ingin mendalami ilmu-ilmu keagamaan masih juga dibebani mata pelajaran lain yang tidak relevan dalam jumlah yang cukup banyak. Sebaliknya siswa yang mengambil jurusan IPA harus pula dibebani dengan banyaknya mata pelajaran lain yang tidak berhubungan langsung (Maimun dan Fitri, 2010: 8).

Dalam proses belajar mengajar di madrasah, strategi pembelajaran yang dikembangkan lebih banyak pada "model warisan" ketimbang problem solving, sehingga siswa lebih banyak meniru daripada melahirkan ide baru. Strategi pembelajaran yang demikian, lama kelamaan tidak tahan uji karena tidak mampu menyesuaikan dengan perkembangan dan tuntutan zaman yang semakin maju (Maimun dan Fitri, 2010: 9).

Kemudian kondisi sarana dan prasarana di madrasah juga masih jauh dari harapan. Sejarah berdirinya madrasah biasanya penuh likuliku, dirintis dengan menempati rumah pendirinya, kemudian menerima tanah wakaf, mendapat sumbangan masyarakat untuk membangun gedung, dan akhirnya terwujudlah bangunan sederhana (Asmani, 2013: 72). Oleh karena itu, untuk menjaga eksistensi madrasah masa kini pihak pengelola harus senantiasa berusaha melengkapi sarana dan prasarana yang dibutuhkan. Selain fasilitas utama, seperti kantor dan gedung sekolah untuk proses kegiatan belajar mengajar, dibutuhkan pula gedung perpustakaan, ruang tamu, laboratorium, tempat parkir, koperasi siswa, lapangan olahraga, aula dan lain-lain.

Selanjutnya terkait pendanaan, nampaknya dalam madrasah masih sangat terbatas. Kebanyakan madrasah masih mengandalkan BOS sehingga kegiatan dan fasilitasnya di bawah standar. Pengembangan kegiatan dan kelengkapan sarana tidak bisa dilakukan karena kendala ini (Asmani, 2013: 81). Pengembangan kualitas lembaga pendidikan tanpa kekuatan finansial akan putus di tengah jalan karena tidak memiliki kontinuitas dan konsistensi.

Mengenai output ataululusan madrasahjugabelum bisadibanggakan, baik mengenai intelektualnya maupun spiritualnya. Dari segi intelektual, banyak lulusan madrasah yang prestasinya jauh di bawah sekolah umum 
yang sejenis yang berada di sekitarnya berdasarkan standar nilai ujian nasional (NUN). Dari segi spiritual, masih banyak lulusan madrasah yang dalam setiap perilakunya belum mencerminkan nilai-nilai islami, bahkan tidak jarang yang terlibat dalam perkelahian dan perilaku negatif lainnya (Maimun dan Fitri, 2010: 8). Kondisi ini akan memperburuk penilaian masyarakat terhadap madrasah, karena mereka akan beranggapan tidak ada beda antara output dari madrasah dan sekolah umum.

\section{Simpulan}

Keberadaan pesantren, sekolah dan madrasah terus mengalami perkembangan, setidaknya secara kuantitatif. Jumlah lembaga-lembaga itu senantiasa bertambah dari tahun ke tahun dan tersebar di seluruh Indonesia. Sayangnya secara kualitatif masih menghadapi berbagai problem yang serius walau sedang berusaha untuk diatasi, baik problem dalam input, proses atau outputnya. Di samping itu, perkembangan ilmu pengetahuan, teknologi dan budaya masyarakat menimbulkan tuntutan yang semakin tinggi terhadap standar pendidikan. Apalagi ketika disandarkan bahwa pendidikan merupakan faktor penentu bagi kemajuan peradaban dan kebudayaan bangsa, membuat kelemahan yang ada pada lembaga pendidikan tersebut semakin terasa sekali dan tentunya harus segera diselesaikan dan diatasi bersama-sama.

Oleh karena itu, berangkat dari pemaparan mengenai berbagai problematika di atas, lembaga pendidikan pesantren, sekolah dan madrasah harus segera melakukan pembenahan-pembenahan melalui strategi-strategi baru untuk meningkatkan kemajuan sehingga menjadi lembaga-lembaga pendidikan yang menjajikan masa depan, baik jaminan keilmuan, kepribadian, maupun keterampilan. 


\section{Daftar Pustaka}

Apip, Komponen-Komponen dalam Sistem Pendidikan, www://apip 0103. Blogspot. Com [2 Oktober 2014].

Asmani, Jamal Ma'mur, Kiat Melabirkan Madrasab Unggulan: Merintis dan Mengelola Madrasah yang Kompetitif, Yogyakarta: Diva Press, 2013.

Baharuddin, Manajemen Pendidikan Islam: Transformasi Menuju Sekolab/ Madrasah Unggul, Malang: UIN-Maliki Press, 2010.

Budianto, Wawancara. [8 Oktober 2014].

Daulay, Haidar Putra, Historisitas dan Eksistensi: Pesantren, sekolah dan Madrasah, Yogyakarta: Tiara Wacana, 2001.

--------------------, Sejarah Pertumbuhan dan Pembaharuan Pendidikan Islam di Indonesia, Jakarta: Kencana Prenada Media Group, 2009.

Departemen Pendidikan dan Kebudayaan, Kamus Besar Bahasa Indonesia, Jakarta: Balai Pustaka, 1997.

Deskriptif Statistik Pendidikan Madrasah, www://pendis.kemenag.go.id [5 Oktober 2014].

Dhofier, Zamakhsyari, Tradisi Pesantren: Studi Tentang Pandangan Hidup Kyai, Jakarta: LP3ES, 1994.

Fattah, Nanang, Landasan Manajemen Pendidikan, Bandung: Penerbit Remaja Rosdakarya, 2004.

Jahari, Jaja dan Amirullah Syarbini, Manajemen Madrasab: Teori, Strategi, dan Implementasi, Bandung: Alfabeta, 2013.

Madjid, Nurcholish, Bilik-bilik Pesantren: Sebuah Potret Perjalanan, Jakarta: Paramadina, 1997.

Maimun, Agus dan Agus Zainal Fitri, Madrasab Unggulan: Lembaga Pendidikan Alternatif di Era Kompetitif, Malang: UIN Maliki Press, 2010.

Poerwadarminta, Kamus Umum Bahasa Indonesia, Jakarta: Balai Pustaka, 1976.

Qomar, Mujamil, Manajemen Pendidikan Islam: Strategi Baru Pengelolaan Lembaga Pendidikan Islam, Malang: Erlangga, 2007. 
Rivai, Veithzal, Education Management: Analisis Teori dan Praktik, Jakarta: Rajawali Press, 2009.

Sagala, Syaiful, Manajemen Berbasis Sekolah dan Masyarakat: Strategi Memenangkan Persaingan Mutu, Jakarta: Nimas Multima, 2004.

Syamsudduha, Manajemen Pesantren Teori dan Praktek, Yogyakarta: Graha Guru, 2004.

Tim Pakar Manajemen Pendidikan Universitas Negeri Malang, Manajemen Pendidikan, Analisis Substantif dan Aplikasinya dalam Institusi Pendidikan, Malang: Penerbit Universitas Negeri Malang, 2002.

Yasmadi, Modernisasi Pesantren: Kritik Nurcholish Madjid Terbadap Pendidikan Islam Tradisional, Jakarta: Ciputat Press, 2002. 